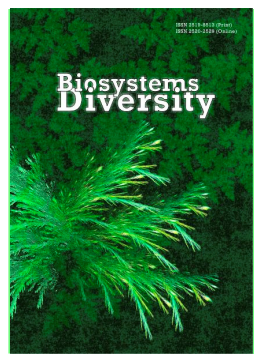

\title{
Influence of air pollution by compounds of fluorine, sulphur and nitrogen on changes of peroxidase and polyphenol oxidase activity in the leaves of trees and bushes
}

\author{
Y. Prysedskyj \\ Vasyl Stus Donetsk National University, Vinnitsa, Ukraine
}

Article info

Received 19.07.2017

Received in revised form 12.08.2017 Accepted 14.08.2017

Vasyl Stus Donetsk National University, 600th anniversary Str., 21, Vinnitsa, 21021, Ukraine Tel.: +38-066-053-24-09.

E-mail:yu.prysedskyi@donnu.edu.ua
Prysedskyj, Y. (2017). Influence of air pollution by compounds of fluorine, sulphur and nitrogen on changes of peroxidase and polyphenol oxidase activity in the leaves of trees and bushes. Biosystems Diversity, 25(3), 216-221. doi:10.15421/011733

Productive activity of man results in contamination of the environment which causes substantial damage to ecosystems, upsetting their balance, species composition, etc. Within industrial areas, plants suffer significant harm. At the same time, plant organisms play an important role in optimization of the environment, performing sanitaryhygienic, landscaping and aesthetic functions. In this context, we investigated the influence of industrial contamination of air by fluorine, sulphur and nitrogen compounds on the activity of peroxidase and polyphenoloxidase in ten types of arboreal and shrub plants which differ in their resistance to air pollution. Our research was conducted on the basis of a full multivariate experiment with two levels of factors. Peroxidase activity was determined by a colorimetric method according to the duration of oxidization of benzidine. For determination of polyphenoloxidase activity we determined the duration of oxidization of $p$-phenilendiamin according to the change in optical density of the solution. Pollutants have a significant influence on activity of the investigated enzymes in the leaves of the plant species studied, which depends on the resistance of the plants to contamination, and also the composition and concentrations of pollutants. With resistant species (Ligustrum vulgare L., Quercus robur L., Lonicera tatarica L., Eleagnus angustifolia L., Philadelphus coronaria L.) peroxidase activity either did not change or rose by $11.2-64.1 \%$ compared to the control. depending on the composition of pollutants, their concentrations and the duration of their activity. Polyphenoloxidase activity in these plants did not significantly change in most variants of the experiment, although high concentrations of pollutants resulted in suppression of the activity of this enzyme by $26.1-37.6 \%$. In species with variable tolerance which did not experience damage, peroxidase function did not change. Species sensitive to pollutants (Sorbus aucuparia L., Fraxinus lanceolata Borkh) were characterized by the significant decline in peroxidase and polyphenoloxidase activity, by $18.7-79.1 \%$ and $20.5-71.2 \%$ respectively, depending on the duration of action of the gases in all variants of the experiment. In species with variable tolerance (Aesculus hippocastanum L., Acer negundo L., Populus simonii Carriere) the reaction to the pollutants was ambiguous in nature and depended on the presence of damage. If the leaves of these plants did not show visible damage (necrosis), then activity of the enzymes did not change. When there was damage to leaf laminae this index decreased in relation to control by $17.3-60.1 \%$ for peroxidase and $24.7-57.3 \%$ for polyphenoloxidase. Significant negative linear correlation was found between activity of antioxidant enzymes and damage to leaves of the investigated plants: the coefficients of correlation were -0.385 between peroxidase activity and damage and -0.130 between polyphenoloxidase activity and damage. The character of changes in peroxidase and polyphenoloxidase activity show that these enzymes play a considerable role in the detoxication of pollutants and that there is a reduction in their influence on metabolic processes of plant organisms.

\section{Вплив забруднення повітря сполуками фтору, сірки та азоту на активність пероксидази та поліфенолоксидази у листках деревних і чагарникових рослин}

\section{Ю. Г. Приседський \\ Донецький національний університет імені Василя Стуса, Вінниця, Украӥна}

Виробнича діяльність людини забруднює довкілля, що чинить суттєвий негативний вплив на екосистеми, порушуючи їх баланс, видовий склад тощо. Значної небезпеки у промислових районах зазнають рослини. Рослинні організми відіграють важливу роль в оптимізації довкілля, виконуючи санітарно-гігієнічну, архітектурно-планувальну та естетичну функції. У зв'язку з цим ми досліджували вплив промислового забруднення повітря комплексом сполук фтору, сірки та азоту на активність пероксидази та поліфенолоксидази у 
десяти видів деревних і чагарникових рослин, що різняться стійкістю до забруднення повітря. Досліди вели за схемою повного багатофакторного експерименту з двома рівнями факторів. Активність пероксидази визначали колориметричним методом за часом окиснення бензидину. Для визначення активності поліфенолоксидази встановлювали термін окиснення $n$-фенілендіаміну за зміною оптичної густини розчину. Отримані результати оброблені статистично за допомогою дисперсійного аналізу та множинного порівняння середніх. Полютанти чинять вірогідний вплив на активність досліджуваних ферментів у листках рослин, який залежить від стійкості виду до забруднення, складу та концентрацій забруднювачів. У стійких видів (Ligustrum vulgare L., Quercus robur L., Lonicera tatarica L., Eleagnus angustifolia L., Philadelphus coronaria L.) активність пероксидази або не змінюється, або підвищується на 11,2-64,1\% порівняно 3 контролем залежно від складу забруднювачів їх концентрацій та терміну дії. Активність поліфенолоксидази у цих видів у більшості варіантів досліду не зазнала вірогідних змін, хоча високі концентрації полютантів спричинили пригнічення активності ферменту на 26,137,6\%. У видів зі змінною стійкістю за відсутності пошкоджень пероксидазна функція не змінюється. Чутливі до полютантів види (Sorbus aucuparia L. та Fraxinus lanceolata Borkh) характеризуються вірогідним зниженням активності пероксидази та поліфенолоксидази на 18,779,1\% та 20,5-71,2\%, відповідно, залежно від терміну дії газів у всіх варіантах досліду. У видів зі змінною стійкістю (Aеsculus hippocastanum L., Acer negundo L. та Populus simonii Carriere) реакція відповіді неоднозначна (залежить від наявності пошкоджень). Якщо листя цих рослин не має видимих пошкоджень (некрозів), активність ферментів не змінюється. За наявності уражень листкових пластинок цей показник знижувався відносно контролю на 17,3-60,1\% для пероксидази та 24,7-57,3\% для поліфенолоксидази. Виявлено негативну вірогідну лінійну кореляцію між активністю антиоксидантних ферментів і пошкоджуваністю листя досліджуваних рослин: коефіцієнти кореляції становлять $-0,385$ між активністю пероксидази та пошкоджуваністю та $-0,130$ між активністю поліфенолоксидази та пошкоджуваністю. Характер змін активності пероксидази та поліфенолоксидази дозволяє зробити висновок про значну роль ферментів у детоксикації полютантів і зменшенні їх впливу на обмінні процеси в рослинних організмах.

Ключові слова: стійкість рослин; комплексне забруднення повітря; антиоксидантні ферменти

\section{Вступ}

Антропогенне забруднення довкілля токсичними речовинами, що утворюються під час виробничої діяльності людини, останнім часом набуло значення глобального екологічного чинника, який впливає на всі елементи екосистем (Sutinen, 1996; Bergman, 1999; Pertti, 2001; Mandal, 2006; Gandstase et al., 2013; Durga et al., 2015; Jing et al., 2016; Lykholat et al., 2016a, 2016b). Особливо значущі зміни довкілля характерні для України, де сконцентровані потужні підприємства хімічної, металургійної, енергетичної та інших галузей промисловості із застарілими технологіями. Il'kun (1978) виділив особливий тип забруднення - український, який характеризується великим різноманіттям, високими концентраціями та далеким перенесенням полютантів. Такі характеристики визначають небезпеку не тільки для України, а i для суміжних країн. Забруднення довкілля спричиняє зміни анатомічної будови (Sharma et al., 1980) значне обмеження процесів життєдіяльності рослин (Soda, 2000; Dizengremel, 2001; Madan, 2015), пригнічує стійкість до несприятливих умов (Geisa, 2016), знижує їх продуктивність (Pack, 1971; Ganatsasa et al., 2011), викликає зменшення генетичної мінливості, таксономічного різноманіття та загибель рослин (Amundson, 1990; Kozyrenko, 2007).

Один із процесів у рослинних організмах, який спричинюється різними несприятливими факторами середовища, - оксидативний стрес, викликаний накопиченням активних форм оксигену та вільних радикалів. Накопичення окиснених речовин і активних форм кисню може викликати низькі температури, порушення балансу між діоксидом карбону та оксигеном (Luma et al., 2016), дія важких металів і засолення грунту (Klumpp et al., 2000), забруднення атмосферного повітря (Langebartels et al., 2002; Frei et al., 2012; Czegeny et al., 2016).

Велике значення у реакціях толерантності рослин до стресових умов довкілля, зокрема, забруднення промисловими полютантами, має антиоксидантна система. Одна зі складових цієї системи оксидоредуктази, зокрема, пероксидаза та поліфенолоксидаза. Як показано багатьма дослідниками, стійкі до стресорів рослини за дії несприятливих умов характеризуються підвищенням активності каталази (Vinnychenko and Dolhova, 2001; Prysedskij, 2016) супероксиддисмутази (Rossychina et al., 2011; Rossychina-Halycha et al., 2014), пероксидази та поліфенолоксидази (Wuytack et al., 2013; Seyyedneja et al., 2013; Wang et al., 2014), тоді як у чутливих рослин, як правило, спостерігається пригнічення активності цих ферментів. Вплив складних комплексів забруднювачів повітря, характерних для промислових зон України, практично не досліджений. У зв'язку з цим вивчено вплив комплексу сполук фтору, азоту та сірки на зміни активності пероксидази та поліфенолоксидази в листках деяких видів деревних і чагарникових рослин.

\section{Матеріал і методи досліджень}

Аналізували десять видів деревних і чагарникових рослин, що різняться за реакцією на комплексне забруднення повітря (Prysedskyj, 2014):

- стійкі види: бирючина звичайна (Ligustrum vulgare L.), дуб звичайний (Quercus robur L.), жимолость татарська (Lonicera tatarica L.), маслинка вузьколиста (Eleagnus angustifolia L.), садовий жасмин звичайний (Philadelphus coronaria L.);

- види зі змінною стійкістю: гіркокаштан звичайний (Aesculus hippocastanum L.), клен ясенелистий (Acer negundo L.), тополя китайська (Populus simonii Carrière);

- нестійкі види: горобина звичайна (Sorbus aucuparia L.) та ясен ланцетний (Fraxinus lanceolata Borkh).

Вибір цих рослин зумовлений їх значним поширенням у зеленому будівництві степової зони (Lypa, 1977; Antipov, 1979). Пагони дослідних рослин довжиною $30-40 \mathrm{~cm}$ зрізали в районах, що не піддаються хронічному забрудненню повітря, та поміщали у колби з водою. Далі їх переміщували у дослідний відсік фумігаційної камери (Popov and Nehruc'ka, 1973), в який подавали суміш аміаку, флуориду гідрогену, сірчистого ангідриду та парів сірчаної кислоти згідно зі схемою повного дворівневого багатофакторного експерименту (табл. 1). Контрольні пагони містилися в контрольному відсіку камери та дії полютантів не піддавалися.

Таблиця 1

Концентрації забруднювачів (мг/м³)

\begin{tabular}{crrrc}
\hline № варіанта & $\mathrm{NH}_{3}$ & $\mathrm{HF}$ & $\mathrm{SO}_{2}$ & $\mathrm{H}_{2} \mathrm{SO}_{4}$ \\
\hline 1 & 1,2 & 0,2 & 1,0 & 0,9 \\
2 & 12,0 & 0,2 & 1,0 & 0,9 \\
3 & 1,2 & 2,0 & 1,0 & 0,9 \\
4 & 12,0 & 2,0 & 1,0 & 0,9 \\
5 & 1,2 & 0,2 & 10,0 & 9,0 \\
6 & 12,0 & 0,2 & 10,0 & 9,0 \\
7 & 1,2 & 2,0 & 10,0 & 9,0 \\
8 & 12,0 & 2,0 & 10,0 & 9,0 \\
\hline
\end{tabular}

Активність пероксидази визначали колориметричним методом за часом окиснення бензидину (за Бояркіним). Для визначення активності поліфенолоксидази встановлювали термін окиснення $n$-фенілендіаміну (Bojko et al., 2014). Крім того у дослідних і контрольних рослин визначали площу некротизованих тканин у відсотках до загальної площі листків (пошкоджуваність). Усі вимірювання проводили у десятиразовій повторності. Вірогідність впливу забруднення на активність ферментів установлювали методом дисперсійного аналізу, порівняння середніх - методом Дункана. Також обчислювали коефіцієнт кореляції між пошкоджуваністю листків і активністю ферментів (Prysedskyj, 1999). Обробку проводили за допомогою пакета статистичних програм, створених на кафедрі фізіології рослин ДонНУ (Prysedskyj, 2005). 


\section{Результати та їх обговорення}

Результати досліджень свідчать про значні розходження в активності пероксидази у різних видів у відповідь на забруднення атмосфери (табл. 2). Активність пероксидази у стійких видів (бирючина звичайна, дуб звичайний, жимолость татарська, маслинка вузьколиста та чубушник вінцевий) за дії більшості варіантів забруднення не змінилася. Високі концентрації аміаку (варіант 2) зумовили збільшення активності пероксидази на 27,5\% та 161,1\% у бирючини звичайної та дуба звичайного, відповідно. У бирючини звичайної, жимолості татарської та маслинки вузьколистої також спостерігали вірогідне підвищення пероксидазної функції на 24,2-64,1\% порівняно $з$ контрольними рослинами за комплексної дії всіх полютантів (варіант 8). Суміш високих концентрацій $\mathrm{HF}, \mathrm{SO}_{2}$ та парів $\mathrm{H}_{2} \mathrm{SO}_{4}$ (варіант 7) викликала зростання активності ферменту на 21,4\% після п'ятигодинної дії ексгалатів. Десятигодинна обробка рослин цього виду викликала пригнічення пероксидази на $22,5 \%$ порівняно з рослинами, що не піддавали впливу токсикантів. Для жимолості татарської характерне збільшення активності пероксидази на 27,3-43,4\% за дії суміші аміаку та фтористого водню (варіант 4) та на 46,2-69,0\% за дії комплексу кислих газів (варіант 6). У маслинки звичайної вірогідне зростання пероксидазної активності характерне для п'ятигодинного впливу фтористого водню (варіант 3 - на 35,3\%) та суміші фторидів та сірчистих сполук (варіант 7 - на 44,9\%). Десятигодинна дія високої концентрації аміаку (варіант 2), навпаки, пригнічувала активність ферменту на 27,0\% порівняно 3 контрольними рослинами. У чубушника відбувалося активування пероксидази за дії $\mathrm{HF}$ (варіант 3) і сполук аміаку із сірчистими сполуками (варіант 6). За цих умов активність ферменту становила $120,5-142,2 \%$ від рівня рослин, що не піддавали фумігації. Разом із цим, дія сірчистих сполук (варіант 5) викликала пригнічення активності ферменту на 32,6\% після десятигодинної дії полютантів.

\section{Таблиця 2}

Зміни активності пероксидази та поліфенолоксидази в умовах забруднення повітря $(\mathrm{n}=10)$

\begin{tabular}{|c|c|c|c|c|c|c|}
\hline \multirow{2}{*}{$\begin{array}{c}\text { Варі- } \\
\text { ант } \\
\text { дослі } \\
\text { ду }\end{array}$} & \multirow{2}{*}{$\begin{array}{l}\text { Термін } \\
\text { дії } \\
\text { токси- } \\
\text { кантів, } \\
\text { год. }\end{array}$} & \multirow{2}{*}{$\begin{array}{c}\text { Пошкод- } \\
\text { жуваність } \\
\text { листя, \% } \\
\text { від площі } \\
\text { листка }\end{array}$} & \multicolumn{2}{|c|}{$\begin{array}{l}\text { Активність пероксидази, } \\
\text { ум. од. }\end{array}$} & \multicolumn{2}{|c|}{$\begin{array}{c}\text { Активність } \\
\text { поліфенолоксидази, ум. од. }\end{array}$} \\
\hline & & & $\mathrm{M} \pm \mathrm{m}$ & $\begin{array}{l}\text { \% до кон- } \\
\text { тролю }\end{array}$ & $\mathrm{M} \pm \mathrm{m}$ & $\begin{array}{l}\text { \% до кон- } \\
\text { тролю }\end{array}$ \\
\hline \multicolumn{7}{|c|}{ Бирючина звичайна (Ligustrum vulgaris L.) } \\
\hline \multirow{3}{*}{1} & $\bar{K}$ & 0 & $31,67 \pm 3,48$ & 100,0 & $17,11 \pm 0,93$ & $\overline{100,0}$ \\
\hline & 5 & 0 & $35,23 \pm 1,84$ & 111,2 & $22,17 \pm 1,31^{* *}$ & 129,6 \\
\hline & 10 & 0 & $41,83 \pm 2,77 * *$ & 132,1 & $17,67 \pm 1,42$ & 101,8 \\
\hline \multirow{3}{*}{2} & $\bar{K}$ & 0 & $30,30 \pm 1,94$ & 100,0 & $22,93 \pm 1,50$ & 100,0 \\
\hline & 5 & 0 & $30,00 \pm 2,42$ & 99,0 & $18,52 \pm 1,55^{* *}$ & 80,8 \\
\hline & 10 & 0 & $38,64 \pm 2,67^{* *}$ & 127,5 & $16,88 \pm 1,02^{* *}$ & 73,6 \\
\hline \multirow{3}{*}{3} & K & 0 & $35,07 \pm 1,22$ & 100,0 & $27,04 \pm 0,54$ & 100,0 \\
\hline & 5 & 0 & $35,79 \pm 2,10$ & 102 & $17,40 \pm 1,39 * *$ & 64,4 \\
\hline & 10 & 0 & $39,55 \pm 2,26$ & 112,8 & $20,07 \pm 1,19^{* *}$ & 74,2 \\
\hline \multirow{3}{*}{4} & K & 0 & $32,41 \pm 3,04$ & 100,0 & $16,02 \pm 1,09$ & 100,0 \\
\hline & 5 & 0 & $33,86 \pm 1,91$ & 104,5 & $13,54 \pm 1,06$ & 84,5 \\
\hline & 10 & 0 & $39,00 \pm 2,25$ & 120,3 & $16,90 \pm 1,38$ & 105,5 \\
\hline \multirow{3}{*}{5} & K & 0 & $32,85 \pm 2,04$ & 100,0 & $21,33 \pm 1,77$ & 100,0 \\
\hline & 5 & 0 & $31,38 \pm 1,55$ & 95,5 & $20,27 \pm 0,99$ & 94,2 \\
\hline & 10 & 0 & $37,14 \pm 3,05$ & 113,1 & $22,13 \pm 1,87$ & 102,8 \\
\hline \multirow{3}{*}{6} & $\bar{K}$ & 0 & $28,19 \pm 2,41$ & 100,0 & $28,56 \pm 2,14$ & $\overline{100,0}$ \\
\hline & 5 & 0 & $38,42 \pm 1,84^{* *}$ & 136,3 & $20,03 \pm 1,80^{* *}$ & 70,1 \\
\hline & 10 & 0 & $41,11 \pm 2,56^{* *}$ & 145,8 & $21,93 \pm 1,55^{* *}$ & 76,8 \\
\hline \multirow{3}{*}{7} & $\bar{K}$ & 0 & $35,87 \pm 1,36$ & 100,0 & $17,47 \pm 0,90$ & 100,0 \\
\hline & 5 & 0 & $43,54 \pm 2,04 * *$ & 121,4 & $17,20 \pm 1,06$ & 98,5 \\
\hline & 10 & $6,7 \pm 3,3$ & $27,80 \pm 1,64^{* *}$ & 77,5 & $12,32 \pm 0,79 * *$ & 70,5 \\
\hline \multirow{3}{*}{8} & $\bar{K}$ & 0 & $28,29 \pm 3,48$ & 100,0 & $24,28 \pm 1,01$ & 100,0 \\
\hline & 5 & 0 & $39,61 \pm 1,84^{* *}$ & 140,0 & $25,86 \pm 0,69$ & 106,5 \\
\hline & 10 & $16,7 \pm 3,0$ & $25,47 \pm 2,77$ & 90,0 & $17,11 \pm 0,93^{* *}$ & 70,5 \\
\hline \multicolumn{7}{|c|}{ Дуб звичайний (Quercus robur L.) } \\
\hline \multirow{3}{*}{1} & K & 0 & $22,01 \pm 2,12$ & 100,0 & $21,27 \pm 1,56$ & 100,0 \\
\hline & 5 & 0 & $26,50 \pm 1,73$ & 120,4 & $26,02 \pm 1,63$ & 122,3 \\
\hline & 10 & 0 & $28,03 \pm 1,67$ & 127,4 & $24,95 \pm 1,20$ & 117,3 \\
\hline \multirow{3}{*}{2} & K & 0 & $19,92 \pm 2,59$ & 100,0 & $23,96 \pm 1,27$ & 100,0 \\
\hline & 5 & 0 & $53,20 \pm 31,50^{* *}$ & 267,1 & $27,94 \pm 2,59$ & 116,6 \\
\hline & 10 & 0 & $24,05 \pm 1,89$ & 120,7 & $29,69 \pm 1,03 * *$ & 123,9 \\
\hline
\end{tabular}

\begin{tabular}{|c|c|c|c|c|c|c|}
\hline \multirow{2}{*}{$\begin{array}{c}\text { Варi- } \\
\text { ант } \\
\text { дослі } \\
\text { ду } \\
\end{array}$} & \multirow{2}{*}{$\begin{array}{c}\text { Термін } \\
\text { дії } \\
\text { токси- } \\
\text { кантів, } \\
\text { год. }\end{array}$} & \multirow{2}{*}{$\begin{array}{c}\text { Пошкод- } \\
\text { жуваність } \\
\text { листя, \% } \\
\text { від площі } \\
\text { листка }\end{array}$} & \multicolumn{2}{|c|}{$\begin{array}{l}\text { Активність пероксидази, } \\
\text { ум. од. } \\
\end{array}$} & \multicolumn{2}{|c|}{$\begin{array}{c}\text { Активність } \\
\text { поліфенолоксидази, ум. од. }\end{array}$} \\
\hline & & & $\mathrm{M} \pm \mathrm{m}$ & $\begin{array}{l}\text { \% до кон- } \\
\text { тролю }\end{array}$ & $\mathrm{M} \pm \mathrm{m}$ & $\begin{array}{l}\text { \% до кон- } \\
\text { тролю }\end{array}$ \\
\hline \multirow{3}{*}{3} & $\mathrm{~K}$ & 0 & $17,53 \pm 1,80$ & 100,0 & $27,30 \pm 2,26$ & 100,0 \\
\hline & 5 & 0 & $27,74 \pm 1,47$ & 158,2 & $31,85 \pm 1,65$ & 116,7 \\
\hline & 10 & 0 & $27,87 \pm 3,44$ & 159,0 & $35,39 \pm 2,62^{* *}$ & 129,6 \\
\hline \multirow{3}{*}{4} & $\mathrm{~K}$ & 0 & $23,87 \pm 1,50$ & 100,0 & $21,96 \pm 1,66$ & 100,0 \\
\hline & 5 & $8,3 \pm 1,7$ & $25,48 \pm 1,17$ & 106,7 & $27,60 \pm 1,20^{* *}$ & 125,7 \\
\hline & 10 & $13,3 \pm 1,7$ & $25,37 \pm 1,71$ & 106,3 & $29,68 \pm 1,07^{* *}$ & 135,2 \\
\hline & $\mathrm{K}$ & 0 & $17,83 \pm 1,59$ & 100,0 & $27,81 \pm 2,01$ & 100,0 \\
\hline 5 & 5 & 0 & $26,26 \pm 1,80$ & 147,3 & $24,42 \pm 1,26$ & 87,8 \\
\hline & 10 & 0 & $23,34 \pm 1,29$ & 130,9 & $21,61 \pm 1,51^{* *}$ & 77,7 \\
\hline & $\mathrm{K}$ & 0 & $24,48 \pm 1,81$ & 100,0 & $20,66 \pm 2,88$ & 100,0 \\
\hline 6 & 5 & 0 & $24,03 \pm 2,38$ & 98,2 & $23,77 \pm 1,15$ & 115,1 \\
\hline & 10 & 0 & $23,44 \pm 2,00$ & 95,8 & $22,21 \pm 2,00$ & 107,5 \\
\hline & K & 0 & $16,92 \pm 1,61$ & 100,0 & $30,25 \pm 1,66$ & 100,0 \\
\hline 7 & 5 & 0 & $21,06 \pm 1,53$ & 124,5 & $25,30 \pm 1,57$ & 83,6 \\
\hline & 10 & 0 & $16,89 \pm 1,92$ & 99,8 & $22,88 \pm 1,19 * *$ & 75,6 \\
\hline & $\mathrm{K}$ & 0 & $21,77 \pm 0,81$ & 100,0 & $25,55 \pm 1,87$ & 100,0 \\
\hline 8 & 5 & 0 & $23,51 \pm 1,99$ & 108,0 & $18,87 \pm 1,90^{* *}$ & 73,9 \\
\hline & 10 & 0 & $17,36 \pm 2,26$ & 79,7 & $15,94 \pm 1,09 * *$ & 62,4 \\
\hline & & Жимо & олость татарська & a (Lonicera ta & atarica $\mathrm{L}$.) & \\
\hline & 10 & 0 & $23,03 \pm 1,48$ & 100,0 & $25,00 \pm 2,03$ & 100,0 \\
\hline 1 & 5 & 0 & $25,23 \pm 1,71$ & 109,6 & $21,80 \pm 0,91$ & 122,3 \\
\hline & 10 & & $20,82 \pm 1,27$ & 90,4 & $33,69 \pm 1,62 * *$ & 117,3 \\
\hline & $\mathrm{K}$ & 0 & $20,56 \pm 1,86$ & 100,0 & 20,10 й 1,72 & 100,0 \\
\hline 2 & 5 & 0 & $24,01 \pm 1,24$ & 116,8 & $25,69 \pm 2,25^{* *}$ & 116,6 \\
\hline & 10 & 0 & $20,71 \pm 2,27$ & 100,7 & $27,48 \pm 0,81^{* *}$ & 123,9 \\
\hline & $\mathrm{K}$ & 0 & $26,64 \pm 1,93$ & 100,0 & $22,11 \pm 1,79$ & 100,0 \\
\hline 3 & 5 & 0 & $23,33 \pm 0,93$ & 87,6 & $25,89 \pm 2,30$ & 116,7 \\
\hline & 10 & 0 & $19,72 \pm 1,26^{* *}$ & 74,0 & $23,29 \pm 1,49$ & 129,6 \\
\hline & $\mathrm{K}$ & 0 & $23,07 \pm 1,62$ & 100,0 & $19,48 \pm 1,29$ & 100,0 \\
\hline 4 & 5 & 0 & $29,37 \pm 1,20 * *$ & 127,3 & $27,01 \pm 2,39 * *$ & 125,7 \\
\hline & 10 & 0 & $33,07 \pm 2,22 * *$ & 143,4 & $22,67 \pm 1,29$ & 135,2 \\
\hline & $\mathrm{K}$ & 0 & $19,88 \pm 1,38$ & 100,0 & $23,88 \pm 1,96$ & 100,0 \\
\hline 5 & 5 & 0 & $22,52 \pm 1,73$ & 113,3 & $41,86 \pm 1,53 * *$ & 87,8 \\
\hline & 10 & 0 & $20,46 \pm 1,70$ & 102,9 & $23,85 \pm 2,12$ & 77,7 \\
\hline & $\mathrm{K}$ & 0 & $26,52 \pm 1,49$ & 100,0 & $24,48 \pm 1,42$ & 100,0 \\
\hline 6 & 5 & 0 & $23,98 \pm 1,10$ & 90,4 & $27,61 \pm 1,39^{* *}$ & 115,1 \\
\hline & 10 & 0 & $24,74 \pm 2,01$ & 93,3 & $26,00 \pm 1,82$ & 107,5 \\
\hline & $\mathrm{K}$ & 0 & $23,06 \pm 1,46$ & 100,0 & $27,52 \pm 1,80$ & 100,0 \\
\hline 7 & 5 & 0 & $33,72 \pm 1,44 * *$ & 146,2 & $18,79 \pm 1,47 * *$ & 83,6 \\
\hline & 10 & $9,7 \pm 0,3$ & $38,97 \pm 0,91^{* *}$ & 169,0 & $11,30 \pm 0,76^{* *}$ & 75,6 \\
\hline & $\mathrm{K}$ & 0 & $22,13 \pm 1,51$ & 100,0 & $23,70 \pm 1,25$ & 100,0 \\
\hline 8 & 5 & 0 & $27,48 \pm 1,05^{* *}$ & 124,2 & $25,61 \pm 1,53$ & 73,9 \\
\hline & 10 & $16,7 \pm 1,7$ & $27,82 \pm 2,35^{* *}$ & 125,7 & $11,29 \pm 1,11^{* *}$ & 62,4 \\
\hline & & Маслинк & ка вузьколиста ( & (Eleagnus ans & gustifolia $\mathrm{L}$.) & \\
\hline & $\mathrm{K}$ & 0 & $18,70 \pm 2,00$ & 100,0 & $6,22 \pm 0,32$ & 100,0 \\
\hline 1 & 5 & 0 & $20,51 \pm 1,08$ & 109,7 & $4,56 \pm 0,20 * *$ & 73,3 \\
\hline & 10 & 0 & $16,90 \pm 1,15$ & 90,4 & $3,93 \pm 0,21 * *$ & 63,2 \\
\hline & $\mathrm{K}$ & 0 & $21,16 \pm 1,42$ & 100,0 & $8,01 \pm 0,31$ & 100,0 \\
\hline 2 & 5 & 0 & $19,97 \pm 1,41$ & 94,4 & $3,74 \pm 0,29^{* *}$ & 46,7 \\
\hline & 10 & 0 & $15,44 \pm 1,67 * *$ & 73,0 & $3,79 \pm 0,31^{* *}$ & 47,3 \\
\hline & $\mathrm{K}$ & 0 & $16,63 \pm 1,57$ & 100,0 & $6,93 \pm 0,31$ & 100,0 \\
\hline 3 & 5 & 0 & $22,66 \pm 1,33^{* *}$ & 136,3 & $4,28 \pm 0,35^{* *}$ & 61,8 \\
\hline & 10 & 0 & $18,50 \pm 1,03$ & 111,2 & $4,70 \pm 0,27^{* *}$ & 67,8 \\
\hline & $\mathrm{K}$ & 0 & $13,80 \pm 1,08$ & 100,0 & $9,56 \pm 0,57$ & 100,0 \\
\hline 4 & 5 & 0 & $16,33 \pm 1,44$ & 118,3 & $7,34 \pm 0,46^{* *}$ & 76,8 \\
\hline & 10 & 0 & $16,86 \pm 1,02$ & 122,2 & $7,65 \pm 0,23 * *$ & 80,0 \\
\hline & $\mathrm{K}$ & 0 & $19,81 \pm 0,96$ & 100,0 & $8,30 \pm 0,92$ & 100,0 \\
\hline 5 & 5 & 0 & $19,90 \pm 1,52$ & 100,5 & $7,91 \pm 0,44$ & 95,3 \\
\hline & 10 & 0 & $26,58 \pm 1,85$ & 134,2 & $9,67 \pm 0,29 * *$ & 116,5 \\
\hline & $\mathrm{K}$ & 0 & $18,83 \pm 1,42$ & 100,0 & $7,48 \pm 0,47$ & 100,0 \\
\hline 6 & 5 & 0 & $25,49 \pm 0,64$ & 135,4 & $7,24 \pm 0,39$ & 96,8 \\
\hline & 10 & 0 & $21,63 \pm 0,58$ & 114,9 & $6,04 \pm 0,19 * *$ & 80,8 \\
\hline & $\mathrm{K}$ & 0 & $15,18 \pm 1,85$ & 100,0 & $6,03 \pm 0,54$ & 100,0 \\
\hline 7 & 5 & 0 & $21,99 \pm 1,45^{* *}$ & 144,9 & $7,13 \pm 0,36$ & 118,2 \\
\hline & 10 & $34,6 \pm 1,2$ & $15,58 \pm 1,01$ & 102,6 & $8,92 \pm 0,47$ & 147,9 \\
\hline & $\mathrm{K}$ & 0 & $16,05 \pm 1,25$ & 100,0 & $4,99 \pm 0,35^{* *}$ & 100,0 \\
\hline 8 & 5 & 0 & $26,33 \pm 1,05^{* *}$ & 164,1 & $5,31 \pm 0,33$ & 106,4 \\
\hline & 10 & 0 & $23,12 \pm 0,86^{* *}$ & 144,1 & $4,24 \pm 0,32$ & 85,0 \\
\hline & & Чубуш & іик вінцевий $(P h$ & hiladelphus cc & oronaria L.) & \\
\hline & $\mathrm{K}$ & 0 & $13,68 \pm 1,41$ & 100,0 & $32,52 \pm 1,46$ & 100,0 \\
\hline 1 & 5 & 0 & $10,76 \pm 0,61$ & 78,7 & $33,80 \pm 1,85$ & 97,1 \\
\hline & 10 & 0 & $13,26 \pm 1,79$ & 96,9 & $32,95 \pm 4,03$ & 101,3 \\
\hline & $\bar{K}$ & 0 & $20,63 \pm 1,12$ & 100,0 & $31,59 \pm 1,95$ & 100,0 \\
\hline 2 & 5 & 0 & $18,71 \pm 1,13$ & 90,7 & $36,41 \pm 2,26$ & 115,3 \\
\hline & 10 & 0 & $19,02 \pm 2,14$ & 92,2 & $41,26 \pm 2,22 * *$ & 130,6 \\
\hline 3 & $\mathrm{~K}$ & 0 & $23,06 \pm 1,24$ & 100,0 & $36,48 \pm 2,03$ & 100,0 \\
\hline
\end{tabular}




\begin{tabular}{|c|c|c|c|c|c|c|}
\hline \multirow{4}{*}{$\begin{array}{c}\text { Варі- } \\
\text { ант } \\
\text { дослі } \\
\text { ду }\end{array}$} & \multirow{2}{*}{$\begin{array}{c}\text { Термін } \\
\text { дії } \\
\text { токси- } \\
\text { кантів, } \\
\text { год. } \\
\end{array}$} & \multirow{2}{*}{$\begin{array}{c}\text { Пошкод- } \\
\text { жуваність } \\
\text { листя, \% } \\
\text { від площі } \\
\text { листка } \\
\end{array}$} & \multicolumn{2}{|c|}{$\begin{array}{l}\text { Активність пероксидази, } \\
\text { ум. од. } \\
\end{array}$} & \multicolumn{2}{|c|}{$\begin{array}{c}\text { Активність } \\
\text { поліфенолоксидази, ум. од. }\end{array}$} \\
\hline & & & $\mathrm{M} \pm \mathrm{m}$ & $\begin{array}{l}\text { \% до кон- } \\
\text { тролю }\end{array}$ & $\mathrm{M} \pm \mathrm{m}$ & $\begin{array}{l}\text { \% до кон- } \\
\text { тролю }\end{array}$ \\
\hline & 5 & $6,7 \pm 3,3$ & $28,35 \pm 1,15^{* *}$ & 122,9 & $48,24 \pm 1,48^{* *}$ & 132,2 \\
\hline & 10 & $28,3 \pm 1,7$ & $32,79 \pm 1,48 * *$ & 142,2 & $60,78 \pm 1,40^{* *}$ & 191,3 \\
\hline \multirow{3}{*}{4} & $\mathrm{~K}$ & 0 & $21,75 \pm 1,54$ & 100,0 & $28,06 \pm 1,47$ & 100,0 \\
\hline & 5 & 0 & $17,56 \pm 1,14 * *$ & 80,7 & $30,81 \pm 2,90$ & 109,7 \\
\hline & 10 & 0 & $17,34 \pm 0,69 * *$ & 79,7 & $19,34 \pm 1,49^{* *}$ & 68,8 \\
\hline \multirow{3}{*}{5} & $\mathrm{~K}$ & 0 & $21,15 \pm 1,11$ & 100,0 & $39,62 \pm 1,65$ & 100,0 \\
\hline & 5 & 0 & $24,18 \pm 1,00$ & 114,3 & $36,13 \pm 0,99$ & 91,2 \\
\hline & 10 & 0 & $14,25 \pm 1,44 * *$ & 67,4 & $26,79 \pm 1,84^{* *}$ & 67,6 \\
\hline & K & 0 & $20,72 \pm 1,02$ & 100,0 & $29,23 \pm 1,52$ & 100,0 \\
\hline 6 & 5 & 0 & $24,24 \pm 0,58$ & 117,0 & $23,41 \pm 1,33$ & 80,1 \\
\hline & 10 & 0 & $24,97 \pm 1,17 * *$ & 120,5 & $27,77 \pm 1,25$ & 95,0 \\
\hline & $\mathrm{K}$ & 0 & $28,57 \pm 1,09$ & 100,0 & $38,17 \pm 1,22$ & 100,0 \\
\hline 7 & 5 & 0 & $27,74 \pm 1,73$ & 97,1 & $35,56 \pm 1,53$ & 93,2 \\
\hline & 10 & 0 & $29,03 \pm 1,56$ & 101,6 & $33,73 \pm 1,91^{* *}$ & 88,4 \\
\hline & $\mathrm{K}$ & 0 & $28,58 \pm 1,45$ & 100,0 & $36,64 \pm 2,25$ & 100,0 \\
\hline 8 & 5 & 0 & $29,59 \pm 1,45$ & 103,5 & $41,79 \pm 1,61$ & 114,1 \\
\hline & 10 & 0 & $30,33 \pm 0,70$ & 106,1 & $45,67 \pm 2,33 * *$ & 124,7 \\
\hline & & Гіркокашт & ан звичайний $(A$ & Aesculus hipp & ocastanum L.) & \\
\hline & $\bar{K}$ & 0 & $33,37 \pm 2,85$ & 100,0 & $19,52 \pm 1,68$ & 100,0 \\
\hline 1 & 5 & 0 & $36,03 \pm 1,55$ & 108,0 & $21,29 \pm 1,59$ & 109,1 \\
\hline & 10 & 0 & $40,30 \pm 1,95^{* *}$ & 120,8 & $25,15 \pm 1,62 * *$ & 128,8 \\
\hline & $\mathrm{K}$ & 0 & $31,51 \pm 1,63$ & 100,0 & $24,12 \pm 1,33$ & 100,0 \\
\hline 2 & 5 & 0 & $23,00 \pm 1,30 * *$ & 73,0 & $18,15 \pm 2,34^{* *}$ & 75,3 \\
\hline & 10 & 0 & $26,98 \pm 1,13$ & 85,6 & $14,90 \pm 0,81^{* *}$ & 61,8 \\
\hline & K & 0 & $36,06 \pm 2,37$ & 100,0 & $27,36 \pm 2,15$ & 100,0 \\
\hline 3 & 5 & $28,3 \pm 1,7$ & $27,83 \pm 2,12 * *$ & 77,2 & $22,69 \pm 1,06$ & 82,9 \\
\hline & 10 & $91,3 \pm 2,4$ & $26,53 \pm 1,35^{* *}$ & 73,6 & $26,86 \pm 1,52$ & 98,2 \\
\hline & $\mathrm{K}$ & 0 & $28,71 \pm 1,29$ & 100,0 & $25,30 \pm 2,02$ & 100,0 \\
\hline 4 & 5 & $5,7 \pm 0,7$ & $20,77 \pm 1,12 * *$ & 72,3 & $25,53 \pm 1,61$ & 100,9 \\
\hline & 10 & $16,7 \pm 3,3$ & $21,40 \pm 1,87 * *$ & 74,5 & $13,15 \pm 1,21^{* *}$ & 52,0 \\
\hline & $\mathrm{K}$ & 0 & $31,18 \pm 1,97$ & 100,0 & $20,59 \pm 2,26$ & 100,0 \\
\hline 5 & 5 & 0 & $22,94 \pm 1,33 * *$ & 73,6 & $12,35 \pm 1,09 * *$ & 60,0 \\
\hline & 10 & 0 & $26,75 \pm 2,28$ & 85,8 & $11,91 \pm 1,04^{* *}$ & 57,8 \\
\hline & $\mathrm{K}$ & 0 & $33,06 \pm 1,35$ & 100,0 & $29,25 \pm 1,74$ & 100,0 \\
\hline 6 & 5 & 0 & $27,35 \pm 2,39 * *$ & 82,7 & $32,03 \pm 1,83$ & 109,5 \\
\hline & 10 & 0 & $21,96 \pm 1,41 * *$ & 66,4 & $35,75 \pm 0,95^{* *}$ & 122,2 \\
\hline & $\mathrm{K}$ & 0 & $36,48 \pm 2,38$ & 100,0 & $21,75 \pm 1,33$ & 100,0 \\
\hline 7 & 5 & $36,7 \pm 1,7$ & $28,12 \pm 1,71^{* *}$ & 77,1 & $21,35 \pm 2,22$ & 98,2 \\
\hline & 10 & $56,7 \pm 3,3$ & $26,74 \pm 1,86^{* *}$ & 73,3 & $13,31 \pm 0,88^{* *}$ & 61,2 \\
\hline & $\mathrm{K}$ & 0 & $35,84 \pm 2,71$ & 100,0 & $20,70 \pm 2,09$ & 100,0 \\
\hline 8 & 5 & $14,0 \pm 3,0$ & $18,74 \pm 1,63^{* *}$ & 52,3 & $14,97 \pm 0,93 * *$ & 50,4 \\
\hline & 10 & $36,6 \pm 3,3$ & $13,23 \pm 1,53 * *$ & 36,9 & $12,69 \pm 0,75^{* *}$ & 42,7 \\
\hline & & & Іен ясенелистий & й(Acer negun & do L.) & \\
\hline & K & 0 & $29,61 \pm 1,73$ & 100,0 & $19,84 \pm 1,74$ & 100,0 \\
\hline 1 & 5 & 0 & $27,23 \pm 2,64$ & 92,0 & $21,18 \pm 0,90$ & 106,8 \\
\hline & 10 & 0 & $21,72 \pm 1,74$ & 73,4 & $18,95 \pm 1,19$ & 95,5 \\
\hline & $\mathrm{K}$ & 0 & $30,10 \pm 1,65$ & 100,0 & $21,89 \pm 1,19$ & 100,0 \\
\hline 2 & 5 & 0 & $35,37 \pm 1,94$ & 117,5 & $21,76 \pm 1,91$ & 99,4 \\
\hline & 10 & 0 & $67,61 \pm 9,76^{* *}$ & 224,6 & $24,63 \pm 1,73$ & 112,5 \\
\hline & $\mathrm{K}$ & 0 & $29,15 \pm 1,68$ & 100,0 & $18,85 \pm 1,45$ & 100,0 \\
\hline 3 & 5 & 0 & $20,78 \pm 2,16$ & 71,3 & $19,84 \pm 1,17$ & 105,3 \\
\hline & 10 & $53,3 \pm 1,7$ & $21,86 \pm 1,83$ & 75,0 & $25,79 \pm 1,10^{* *}$ & 136,8 \\
\hline & $\mathrm{K}$ & 0 & $30,48 \pm 1,95$ & 100,0 & $21,71 \pm 1,06$ & 100,0 \\
\hline 4 & 5 & 0 & $33,28 \pm 2,47$ & 109,2 & $14,61 \pm 1,62 * *$ & 67,3 \\
\hline & 10 & $16,7 \pm 1,7$ & $26,70 \pm 2,24$ & 87,6 & $15,40 \pm 1,52 * *$ & 70,9 \\
\hline & K & 0 & $29,04 \pm 2,58$ & 100,0 & $16,65 \pm 1,19$ & 100,0 \\
\hline 5 & 5 & $6,4 \pm 1,3$ & $35,75 \pm 1,95$ & 123,1 & $12,74 \pm 0,70^{* *}$ & 82,7 \\
\hline & 10 & $10,7 \pm 0,7$ & $38,73 \pm 2,22$ & 133,4 & $8,60 \pm 1,33^{* *}$ & 55,8 \\
\hline & $\mathrm{K}$ & & $31,72 \pm 1,85$ & 100,0 & $20,39 \pm 1,01$ & 100,0 \\
\hline 6 & 5 & 0 & $28,37 \pm 2,04$ & 89,4 & $23,28 \pm 1,14$ & 114,7 \\
\hline & 10 & 0 & $20,77 \pm 1,79$ & 65,5 & $25,83 \pm 1,60^{* *}$ & 126,7 \\
\hline & $\mathrm{K}$ & 0 & $27,04 \pm 1,52$ & 100,0 & $23,90 \pm 1,19$ & 100,0 \\
\hline 7 & 5 & $12,8 \pm 3,2$ & $33,89 \pm 2,37$ & 125,3 & $17,21 \pm 0,69^{* *}$ & 72,0 \\
\hline & 10 & $88,3 \pm 3,7$ & $38,81 \pm 1,31$ & 143,5 & $12,73 \pm 1,46^{* *}$ & 53,3 \\
\hline & $\mathrm{K}$ & 0 & $24,31 \pm 2,01$ & 100,0 & $18,44 \pm 1,45$ & 100,0 \\
\hline 8 & 5 & $8,9 \pm 2,1$ & $17,20 \pm 1,96$ & 70,8 & $12,66 \pm 0,96^{* *}$ & 68,7 \\
\hline & 10 & $76,7 \pm 3,3$ & $11,20 \pm 1,08$ & 46,1 & $7,96 \pm 0,97 * *$ & 43,2 \\
\hline & & Топол & Ія китайська $(P o$ & opulus simonit & $i$ Carriere) & \\
\hline & $\bar{K}$ & 0 & $20,15 \pm 1,27$ & 100,0 & $13,86 \pm 0,61$ & 100,0 \\
\hline 1 & 5 & 0 & $22,30 \pm 1,60$ & 110,7 & $14,40 \pm 1,20$ & 103,9 \\
\hline & 10 & $15,3 \pm 2,9$ & $22,95 \pm 1,92$ & 113,9 & $17,31 \pm 1,24$ & 124,9 \\
\hline & $\bar{K}$ & 0 & $22,54 \pm 2,09$ & 100,0 & $15,63 \pm 0,90$ & 100,0 \\
\hline 2 & 5 & 0 & $21,04 \pm 1,06$ & 93,4 & $17,40 \pm 1,34$ & 111,3 \\
\hline & 10 & 0 & $21,25 \pm 1,41$ & 94,3 & $24,48 \pm 1,87^{* *}$ & 156,6 \\
\hline 3 & $\mathrm{~K}$ & 0 & $31,44 \pm 1,87$ & 100,0 & $16,52 \pm 1,50$ & 100,0 \\
\hline
\end{tabular}

\begin{tabular}{|c|c|c|c|c|c|c|}
\hline \multirow{2}{*}{$\begin{array}{l}\text { Bapi- } \\
\text { ант } \\
\text { дослі } \\
\text { ду }\end{array}$} & \multirow{2}{*}{$\begin{array}{l}\text { Термін } \\
\text { дії } \\
\text { токси- } \\
\text { кантів, } \\
\text { год. } \\
\end{array}$} & \multirow{2}{*}{$\begin{array}{c}\text { Пошкод- } \\
\text { жуваність } \\
\text { листя, \% } \\
\text { від площі } \\
\text { листка }\end{array}$} & \multicolumn{2}{|c|}{$\begin{array}{c}\text { Активність пероксидази, } \\
\text { ум. од. } \\
\end{array}$} & \multicolumn{2}{|c|}{$\begin{array}{c}\text { Активність } \\
\text { поліфенолоксидази, ум. од. }\end{array}$} \\
\hline & & & $\mathrm{M} \pm \mathrm{m}$ & $\begin{array}{l}\text { \% до кон- } \\
\text { тролю }\end{array}$ & $\mathrm{M} \pm \mathrm{m}$ & $\begin{array}{c}\text { \% до кон- } \\
\text { тролю }\end{array}$ \\
\hline & 5 & 0 & $39,75 \pm 2,62 * *$ & 126,4 & $16,08 \pm 0,96$ & 97,3 \\
\hline & 10 & 0 & $37,62 \pm 3,12^{* *}$ & 119,7 & $9,53 \pm 1,31 * *$ & 57,7 \\
\hline \multirow{3}{*}{4} & $\mathrm{~K}$ & 0 & $18,43 \pm 1,47$ & 100,0 & $12,48 \pm 0,97$ & 100,0 \\
\hline & 5 & 0 & $22,76 \pm 1,35$ & 123,5 & $9,33 \pm 1,31$ & 74,8 \\
\hline & 10 & $6,7 \pm 1,7$ & $19,69 \pm 1,50$ & 106,8 & $6,77 \pm 0,47 * *$ & 54,3 \\
\hline \multirow{3}{*}{5} & $\mathrm{~K}$ & 0 & $29,48 \pm 2,47$ & 100,0 & $16,62 \pm 1,83$ & 100,0 \\
\hline & 5 & 0 & $25,19 \pm 1,90$ & 85,5 & $14,99 \pm 1,36$ & 90,2 \\
\hline & 10 & 0 & $18,48 \pm 1,02 * *$ & 62,7 & $26,69 \pm 1,46^{* *}$ & 157,0 \\
\hline \multirow{3}{*}{6} & $\mathrm{~K}$ & 0 & $28,11 \pm 1,85$ & 100,0 & $10,68 \pm 1,91$ & 100,0 \\
\hline & 5 & $17,6 \pm 3,1$ & $26,54 \pm 3,03$ & 94,4 & $8,16 \pm 0,65$ & 76,4 \\
\hline & 10 & $33,5 \pm 2,7$ & $34,40 \pm 2,39 * *$ & 122,4 & $6,28 \pm 0,61 * *$ & 58,8 \\
\hline \multirow{3}{*}{7} & $\mathrm{~K}$ & 0 & $21,46 \pm 2,24$ & 100,0 & $14,37 \pm 1,12$ & 100,0 \\
\hline & 5 & $31,7 \pm 3,5$ & $31,19 \pm 1,88^{* *}$ & 145,3 & $12,68 \pm 1,08$ & 88,2 \\
\hline & 10 & $60,7 \pm 1,6$ & $33,54 \pm 1,75^{* *}$ & 156,3 & $10,46 \pm 1,52^{* *}$ & 72,8 \\
\hline \multirow{3}{*}{8} & $\mathrm{~K}$ & 0 & $31,77 \pm 2,84$ & 100,0 & $15,16 \pm 1,35$ & 100,0 \\
\hline & 5 & $46,7 \pm 2,1$ & $29,61 \pm 2,30^{* *}$ & 93,2 & $11,91 \pm$ & 78,6 \\
\hline & 10 & $71,6 \pm 1,7$ & $20,28 \pm 0,69^{* *}$ & 63,8 & $6,65 \pm 0$ & 43,8 \\
\hline \multicolumn{7}{|c|}{ Горобина звичайна (Sorbus aucuparia L.) } \\
\hline & $\bar{K}$ & 0 & $36,06 \pm 1,69$ & 100,0 & $25,20 \pm 1,16$ & 100,0 \\
\hline 1 & 5 & 0 & $=1,52 * *$ & 63,8 & $30,39 \pm$ & 120,6 \\
\hline & 10 & 0 & $21,54 \pm 1,62 * *$ & 59,7 & $19,40 \pm 2,00^{* *}$ & 77,0 \\
\hline & $\mathrm{K}$ & 0 & $32,37 \pm 2,54$ & 100,0 & $25,77 \pm 1,31$ & 100,0 \\
\hline 2 & 5 & $6,7 \pm 3,3$ & $21,54 \pm 2,17^{* *}$ & 66,5 & $20,41 \pm 1,59^{* *}$ & 79,2 \\
\hline & 10 & $28,3 \pm 4,4$ & $22,30 \pm 1,41^{* *}$ & 68,9 & $15,71 \pm 1,57^{* *}$ & 61,0 \\
\hline & K & 0 & $29,64 \pm 1,37$ & 100,0 & $28,54 \pm 1,28$ & 100,0 \\
\hline 3 & 5 & $12,0 \pm 2,0$ & $15,86 \pm 1,94^{* *}$ & 53,5 & $27,08 \pm$ & 94,9 \\
\hline & 10 & $31,0 \pm 3,8$ & $16,93 \pm 0,95^{* *}$ & 57,1 & $13,85 \pm 1,39^{* *}$ & 48,5 \\
\hline & $\mathrm{K}$ & 0 & $36,45 \pm 1,64$ & 100,0 & $24,45 \pm 1,53$ & 100,0 \\
\hline 4 & 5 & $18,3 \pm 1,7$ & $26,39 \pm 0,99^{* *}$ & 72,4 & $30,87 \pm 1,14^{* *}$ & 126,3 \\
\hline & 10 & $58,3 \pm 4,4$ & $26,02 \pm 0,98^{* *}$ & 71,4 & $18,74 \pm 1,56^{* *}$ & 76,7 \\
\hline & K & 0 & $30,37 \pm 2,49$ & 100,0 & $32,39 \pm 1,48$ & 100,0 \\
\hline 5 & 5 & 0 & $18,61 \pm 2,00^{* *}$ & 61,3 & $24,77 \pm 1,00^{* *}$ & 76,5 \\
\hline & 10 & $16,7 \pm 3,3$ & $13,47 \pm 0,90^{* *}$ & 44,4 & $20,78 \pm 1,42^{* *}$ & 64,2 \\
\hline & $\mathrm{K}$ & 0 & $\pm 1,79$ & 100,0 & $27,15 \pm 1,80$ & 100,0 \\
\hline 6 & 5 & $23,3 \pm 1,6$ & $23,28 \pm 1,01 * *$ & 68,8 & $14,64 \pm 1,65^{* *}$ & 53,9 \\
\hline & 10 & $73,3 \pm 1,7$ & $17,17 \pm 1,30^{* *}$ & 50,9 & $14,54 \pm 1$ & 53,6 \\
\hline & $\mathrm{K}$ & 0 & $\pm 1,53$ & 100,0 & $20,93 \pm 1,90$ & 100,0 \\
\hline 7 & 5 & $28,3 \pm 1,7$ & $15,20 \pm 1,40^{* *}$ & 50,8 & $19,32 \pm 2,01$ & 92,3 \\
\hline & 10 & $58,3 \pm 1,7$ & $12,23 \pm 1,61^{* *}$ & 40,9 & $14,98 \pm 1,18^{* *}$ & 71,6 \\
\hline & $\mathrm{K}$ & 0 & $39,20 \pm 1,95$ & 100,0 & $29,23 \pm 1,20$ & 100,0 \\
\hline 8 & 5 & $25,4 \pm 1,6$ & $13,07 \pm 1,47^{* *}$ & 33,3 & $16,86 \pm 1,84 * *$ & 57,7 \\
\hline & 10 & $73,3 \pm 3,4$ & $8,20 \pm 0,77 * *$ & 20,9 & $8,42 \pm 0,64 * *$ & 28,8 \\
\hline & & & н ланщетний (Fr & lances & olata L.) & \\
\hline & $\bar{K}$ & 0 & $23,08 \pm 2,11$ & 100,0 & $41,01 \pm$ & 100,0 \\
\hline 1 & 5 & $10,0 \pm 2,0$ & $1,64 * *$ & 71,8 & $29,81 \pm$ & 72,7 \\
\hline & 10 & $43,3 \pm 3,3$ & $14,82 \pm 1,08^{* *}$ & 64,2 & $22,11 \pm 1,35^{* *}$ & 53,9 \\
\hline & $\mathrm{K}$ & 0 & $17,40 \pm 1,60$ & 100,0 & $38,11 \pm 1,66$ & 100,0 \\
\hline 2 & 5 & 0 & $12,67 \pm 0,84^{* *}$ & 72,8 & $34,09 \pm 1,91$ & 89,5 \\
\hline & 10 & $73,0 \pm 2,1$ & $8,82 \pm 0,77^{* *}$ & 50,7 & $35,26 \pm 1,62$ & 92,5 \\
\hline & K & 0 & $12,93 \pm 0,89$ & 100,0 & $33,67 \pm 2,20$ & 100,0 \\
\hline 3 & 5 & $13,5 \pm 4,1$ & $11,81 \pm 1,05$ & 91,8 & $34,19 \pm 2,37$ & 101,5 \\
\hline & 10 & $71,7 \pm 6,0$ & $11,24 \pm 1,34$ & 86,9 & $25,26 \pm 2,09^{* *}$ & 75,0 \\
\hline & $\bar{K}$ & 0 & $25,48 \pm 1,57$ & 100,0 & $34,43 \pm 1,57$ & 100,0 \\
\hline 4 & 5 & 0 & $15,28 \pm 1,88^{* *}$ & 60,0 & $31,73 \pm 2,38$ & 92,2 \\
\hline & 10 & $71,7 \pm 1,7$ & $7,52 \pm 0,73^{* *}$ & 29,5 & $18,59 \pm 1,66^{* *}$ & 54,0 \\
\hline & $\mathrm{K}$ & 0 & $12,64 \pm 0,93$ & 100,0 & $38,61 \pm 2,33$ & 100,0 \\
\hline 5 & 5 & 0 & $10,86 \pm 1,02$ & 85,9 & $29,15 \pm 1,61 * *$ & 79,6 \\
\hline & 10 & $51,6 \pm 4,4$ & $9,38 \pm 1,45$ & 74,2 & $28,65 \pm 2,13^{* *}$ & 78,3 \\
\hline & $\mathrm{K}$ & 0 & $20,56 \pm 0,65$ & 100,0 & $35,27 \pm 1,53$ & 100,0 \\
\hline 6 & 5 & $20,1 \pm 3,1$ & $16,71 \pm 1,34 * *$ & 81,3 & $31,06 \pm 1,93$ & 88,1 \\
\hline & 10 & $73,3 \pm 1,7$ & $10,08 \pm 1,44^{* *}$ & 49,0 & $25,15 \pm 2,56^{* *}$ & 71,3 \\
\hline & $\mathrm{K}$ & 0 & $19,30 \pm 0,90$ & 100,0 & $38,38 \pm 1,77$ & 100,0 \\
\hline 7 & 5 & $21,7 \pm 5,3$ & $12,68 \pm 1,04 * *$ & 65,7 & $34,89 \pm 2,82$ & 90,9 \\
\hline & 10 & $73,3 \pm 3,3$ & $9,28 \pm 0,84^{* *}$ & 48,1 & $34,48 \pm 1,61^{* *}$ & 89,8 \\
\hline & $\mathrm{K}$ & 0 & $13,55 \pm 1,07$ & 100,0 & $39,71 \pm 1,93$ & 100,0 \\
\hline 8 & 5 & $15,8 \pm 1,2$ & $7,30 \pm 0,69 * *$ & 53,9 & $25,23 \pm 1,66^{* *}$ & 63,3 \\
\hline & 10 & $82,0 \pm 6,1$ & $2,88 \pm 0,33 * *$ & 21,3 & $15,21 \pm 1,26^{* *}$ & 38,3 \\
\hline
\end{tabular}

Примітки: К - контроль; * - $\mathrm{P}<0,05, * *-\mathrm{P}<0,01, * * *-\mathrm{P}<0,001$ порівняно $з$ контролем.

Зміни активності пероксидази у видів із мінливою стійкістю (гіркокаштан звичайний, клен ясенелистий і тополя китайська) суттєво залежали від пошкоджуваності їх листя, яка, у свою чергу, залежала ві складу забруднювачів та терміну їх дії. У білышості 
варіантів досліду п'ятигодинна дія ексгалатів не викликала вірогідних змін активності пероксидази в листках цих видів, а в ряді випадків за відсутності видимих уражень листків - підвищувалася на 26,4-124,6\% порівняно 3 контролем. За наявності пошкоджень листя, яке охоплювало понад 10-15\% загальної листкової поверхні, у рослин, що характеризувалися мінливою стійкістю, відбувалося вірогідне пригнічення активності пероксидази. Зокрема, гіркокаштан звичайний характеризувався суттєвою чутливістю до фтористого водню (варіант 3), сумішей аміаку та фтористого водню (варіант 4), кислих газів (варіант 7) та всіх полютантів (варіант 8). У цих умовах активність пероксидази в його листках коливалась у межах 36,9-74,5\% від активності контрольних рослин. У клена ясенелистого вірогідне пригнічення функції ферменту викликали дія суміші аміаку та сірчистих сполук (варіант 6 - на 34,5\%) та суміші всіх полютантів (варіант 8 - на 29,2-53,9\%). У тополі китайської вірогідне зниження активності пероксидази спостерігали лише за десятигодинного впливу сірчистих сполук (варіант 5) і суміші всіх газів (варіант 8). За цих умов досліджуваний параметр становив $62,7 \%$ та $63,8 \%$ від контрольних рослин, відповідно.

У нестійких до забруднення повітря видів (горобина звичайна та ясен зелений) відбувалося суттєве зниження активності пероксидази за всіх варіантів забруднення як після п’ятигодинної фумігації, так і після 10 годин впливу полютантів. Так, у горобини звичайної після п'яти годин впливу токсикантів залежно від складу газових сумішей пригнічення пероксидазної функції становило 31,2-67,7\%. Десятигодинна дія токсикантів викликала подальше пригнічення ферменту на 40,3-79,2\% порівняно 3 контролем. У ясена п'ятигодинна дія забруднювачів спричинила зниження ферментативної активності на $14,1-46,1 \%$, а десятигодинна - на 13,1-78,7\% порівняно з рослинами, що не піддавалися дії ексгалатів. Слід звернути увагу на зв'язок між змінами активності пероксидази та пошкоджуваністю листя рослин. Ми виявили вірогідний обернено пропорційний лінійний зв'язок між цими показниками (коефіцієнт кореляції становив $-0,385$, вірогідність коефіцієнта 6,437 , стандартне значення критерію Стьюдента - 1,960, показник лінійності зв'язку дорівнює-0,141).

Визначення змін активності поліфенолоксидази у відповідь на дію комплексного забруднення повітря показало, що у бирючини звичайної, дуба звичайного, жимолості татарської, маслинки вузьколистої та чубушника вінцевого не спостерігалося вірогідних змін активності ферменту майже за всіх варіантів сполучень полютантів за п'ятигодинної їх дії. Десятигодинний вплив ексгалатів викликав пригнічення активності поліфенолоксидази на 29,5-37,6\% порівняно $з$ контролем у бирючини звичайної, дуба звичайного та жимолості татарської у більшості варіантів забруднення повітря.

У маслинки вузьколистої активність ферменту знижувалася на 20,0-53,3\% за дії аміаку (варіант 2), фтористого водню (варіант 3) та їх суміші (варіант 4). Дія суміші $\mathrm{HF}$ та $\mathrm{SO}_{2}$ та парів $\mathrm{H}_{2} \mathrm{SO}_{4}$ викликала підвищення активності поліфенолоксидази $18,2-47,9 \%$ порівняно $з$ контролем. Чубушник характеризувався пригніченням поліфенолоксидазної функції за десятигодинного впливу суміші фтористого водню 3 аміаком (варіант 4) та суміші сірчистих сполук (варіант 5). Фторид водню та комплекс усіх полютантів (варіанти 3 та 8) викликали вірогідне збільшення активності поліфенолоксидази на 91,3\% та 24,7\%, відповідно.

У видів зі змінною стійкістю (гіркокаштан звичайний, клен ясенелистий і тополя китайська) за відсутності видимих уражень листя не зазнавало вірогідних змін за впливу забруднення повітря. Поява некротичних уражень листя спричиняє вірогідне зниження активності цього ферменту на 27,2-57,3\% порівняно з рослинами, що не зазнавали дії газів.

Горобина звичайна та ясен ланцетний (нестійкі види) характеризуються зниженням активності поліфенолоксидази у відповідь на дію комплексного забруднення повітря за п'ятигодинної фумігації на 20,8-71,2\% залежно від складу забруднювачів. Лише за впливу низьких концентрацій забруднювачів у горобини звичайної спостерігали вірогідне зростання поліфенолоксидазної активності на 20,6\% порівняно 3 нефумігова- ними рослинами. Обчислення показників кореляції показало слабку обернено пропорційну залежність між пошкоджуваністю листя та ступенем змін активності поліфенолоксидази: коефіцієнт кореляції - $-0,130$, обчислене значення вірогідності зв'язку - 2,028, стандартне значення критерію Стьюдента 1,960 , показник лінійності зв'язку становить -0.016 .

Отримані результати свідчать, що стійкі до забруднення повітря види характеризувалися підвищенням активності пероксидази на 21,4-161,1\% залежно від складу та концентрацій полютантів. Забруднення повітря кислими $\left(\mathrm{HF}, \mathrm{SO}_{2}\right.$, пари $\mathrm{H}_{2} \mathrm{SO}_{4}$ тощо) та лужними $\left(\mathrm{NH}_{3}\right)$ газами викликає значні зміни $\mathrm{pH}$ клітинного соку (Yan-Ju, 2008), що посилює окисні процеси. Поява вільних радикалів під час окиснення органічних речовин сприяє утворенню пероксидів. Пероксид водню також утворюється під час окиснення фенольних сполук поліфенолоксидазою. Пероксидаза - один із головних ферментів, що руйнує органічні та неорганічні пероксиди. Таким чином, підвищення активності цього ферменту сприяє стабільності оксидантно-антиоксидантної системи (Korostylova, 2014). У нестійких до забруднення видів та видів зі змінною стійкістю за наявності некротичних ушкоджень, викликаних полютантами, активність пероксидази знижувалася на $13,1-78,7 \%$ порівняно 3 контролем. Такі зміни знижували антиоксидантний захист рослин, що, ймовірно, разом із пригніченням інших фізіологічних процесів спричинювало розвиток ушкоджень і появу некрозів на листках. Зміни активності поліфенолоксидази у стійких видів не мали закономірного характеру. У більшості варіантів забруднення іiі активність не зазнавала вірогідних змін або зменшувалася на 29,5-37,6\% порівняно з контролем. У нестійких до забруднення повітря видів рослин у відповідь на дію фітотоксикантів активність поліфенолоксидази значно знижується. Зниження їх активності залежить від ступеня пошкодження листкових пластинок. Такий характер змін активності ферменту може свідчити скоріше про стресове значення ензиму, ніж про антиоксидантне (Prysedskyj, 2017). Аналогічні закономірності встановлені іншими дослідниками за дії полютантів на деревні (Ghorbanli et al., 2007; Koffi et al., 2015; Alexeyeva et al., 2016; Lykholat et al., 2016; Baranovski et al., 2016) та трав'янисті (Kim et al., 2007; Rossykhina-Halycha et al., 2013) рослини.

\section{Висновки}

Досліджувані види відрізняються за реакцією на забруднення повітря сполуками фтору, сірки та азоту. У стійких рослин адаптація до комплексного забруднення повітря полягає у підвищенні активності пероксидази як антиоксидантного ферменту та стабільності активності поліфенолоксидази. Нестійкі види характеризуються вразливою системою антиоксидантного захисту та значними ураженнями листя. Серед досліджуваних видів такими, що не мали некротичних ушкоджень або ушкодження становили не більше $20 \%$ поверхні листя, виявилися бирючина звичайна, дуб звичайний, жимолость татарська, маслинка вузьколиста та чубушник вінцевий.

\section{References}

Alexeyeva, A. A., Lykholat, Y. V., Khromykh, N. O., Kovalenko, I. M., \& Boroday, E. S. (2016). The impact of pollutants on the antioxidant protection of species of the genus Tilia at different developmental stages. Visnyk of Dnipropetrovsk University. Biology, Ecology, 24(1), 188-192.

Amundson, R. G., Belsky, J., \& Dickie, R. C. (1990). Fluoride deposition via litterfall in a coastal-plain pine plantation in south carolina. Water, Air, and Soil Pollution, 50, 301-310.

Antipov, V. G. (1979). Ustojchivost' drevesnyh rastenij k promyshlennym gazam [Stability of woody plants for industrial gases]. Nauka i Texnika, Minsk (in Russian).

Baranovski, B., Khromykh, N., Karmyzova, L., Ivanko, I., \& Lykholat, Y. (2016). Anyalysis of the alien flora of Dnipropetrovsk province. Biological Bulletin of Bogdan Chmelnitskiy Melitopol State Pedagogical University, 6(3), 419-429. 
Bergmaqnn, E., Bender, J., \& Weigel, H.-J. (1999). Ozone threshold doses and exposure - response relationships for the development of ozone injury symptoms in wild plant species. New Phytologist, 144(3), 423-435.

Bojko, M. I., Pryseds'kyj, J. H., \& Vjetrova, O. V. (2014). Velykyj praktykum z fiziolohiji ta biochimiji roslyn (bilky, fermenty, vitaminy, nuklejinovi kysloty) [Large workshop of plant physiology and biochemistry (proteins, enzymes, vitamins, nucleic acids)]. DonNU, Donec'k (in Ukrainian).

Czegeny, G., Matai, A., \& Hide, E. (2016). UV-B effects on leaves - Oxidative stress and acclimation in controlled environments. Plant Science, 248, 57-63.

Dizengremel, P. (2001). Effects of ozone on the carbon metabolism of forest trees. Plant Physiology and Biochemistry, 39(9), 729-742.

Durga, M., Bharathi, S., Balakrishna Murthy, P., \& Devasena, T. (2015). Characterization and hytotoxicity studies of suspended particulate matter (SPM) in Chennai urban area. Journal of Environmental Biology, 36(3), 583-589.

Frei, M., Wissuwa, M., Pariasca-Tanaka, J., Chen, C. P., Sudekum, K-H., \& Kohno, Y. (2012). Leaf ascorbic acid level - Is it really important for ozone tolerance in rice? Plant Physiology and Biochemistry, 59, 63-70.

Ganatsasa, P., Tsakaldimia, M., \& Zachariadis, G. (2011). Effect of air traffic pollution on seed quality characteristics of Pinus brutia. Environmental and Experimental Botany, 74, 157-161.

Geisa, L. M., Dirceu, M. Jr., Francisco, A., Tanaka, C. H., Zambrosi, F. C. B., Caruso, E., \& Driving, M. (2016). Traits tolerance to atmospheric fluoride pollution in tree crops. Water, Air and Soil Pollution, 227, 420-425.

Ghorbanli, M., Bakand, Z., Bakhshikhaniki, G., \& Bakand, S. (2007). Air pollution effects on the activity of antioxidant enzimes in Nerium oleander and Robinia pseudoacacia plants in Teheran. Journal of Environmental Health Science and Engineering, 4, 148-156.

Il'kun, G. M. (1978). Zagryazniteli atmosfery i rasteniya [Atmospheric pollutants and plants]. Naukova Dumka, Kyiv (in Russian).

Jing, L., Dombinov, V., Shen, S., Wu, Y., Yang, L., Wang, Y., \& Frei, M. (2016). Physiological and genotype-specific factors associated with grain quality changes in rice exposed to high ozone. Environmental Pollution, 210, 397-408.

Kim, Y.-H., Lim, S., Han, S.-H., Lee, J.-C., Song, W.-K., Bang, J.-W., Kwon, S.Y., Lee, H.-S., \& Kwak, S.-S. (2007). Differential expression of 10 sweetpotato peroxidases in response to sulfur dioxide, ozone, and ultraviolet radiation. Plant Physiology and Biochemistry, 45(12), 908-914.

Klumpp, G., Furlan, C. M., Domingos, M., \& Klumpp, A. (2000). Response of stress indicators and growth parameters of Tibouchina pulchra Cogn. exposed to air and soil pollution near the industrial complex of Cubatao, Brazil. Science of the Total Environment, 246(1), 79-91.

Koffi, N. A., Maxime, A. D., Barima, Y. S. S., \& Dongui, B. (2015). Detoxifing hydrogen peroxide enzimes activity in two plant species exposed to air pollution in Abidjan city (Cote D'ivoire). International Journal of Plant, Animal and Environmental Sciences, 5(1), 140-145.

Kozyrenko, M. M., Artyukova, E. V., Shmakov, V. N., \& Konstantinov, Y. M. (2007). Effect of fluoride pollution on genetic variability of Larix gmelini (Pinaceae) in East Siberia. Journal of Forest Research, 12, 388-392.

Langebartels, C., Wohlgemuth, H., Kschieschan, S., Grun, S., \& Sandermann, H. (2002). Oxidative burst and cell death in ozone-exposed plants. Plant Physiology and Biochemistry, 40(6), 567-575.

Luma, G. B., Shelpa, B. J., Dell, J. R., \& Bozzo, G. G. (2016). Oxidative metabolism is associated with physiological disorders in fruits stored under multiple environmental stresses. Plant Science, 245, 143-152.

Lykholat, O. A., Grigoryuk, I. P., \& Lykholat, T. Y. (2016). Metabolic effects of alimentary estrogen in different age animals. Annals of Agrarian Science, 14(4), 335-339.

Lykholat, T., Lykholat, O., \& Antonyuk, S. (2016). Immunohistochemical and biochemical analysis of mammary gland tumours of different age patients. Cytology and Genetics, 50(1), 32-41.

Lykholat, Y., Khromyk, N., Ivanko, I., Kovalenko, I., Shupranova, L., \& Kharytonov, M. (2016). Metabolic responses of steppe forest trees to altirude-associated local environmental changes. Agriculture and Forestry, 62(2), 163-171.

Lypa, A. L. (1977). Dendrolohyja z osnovamy aklimatyzaciji [Dendrology with the basics of acclimatization]. Vysha Shkola, Kyiv (in Ukrainian).

Madan, S., \& Verma, P. (2015). Assessment of air pollution tolerance index of some trees in Haridwar City, Uttarakhand. Journal of Environmental Biology, 36(3), 645-648.

Mandal, M. (2006). Physiological changes in certain test plants under automobile exhaust pollution. Journal of Environmental Biology, 27(1), 43-47.

Olszyk, D. M., Takemoto, B. K., \& Poe, M. (1991). Leaf photosynthetic and water relations responses for "Valencia" orange trees exposed to oxidant air pollution. Environmental and Experimental Botany, 31(4), 427-436.
Pack, M. R. (1971). Effects of hydrogen fluoride on bean reproduction. Journal of the Air Pollution Control Association, 21(3), 133-137.

Pertti, R. (2001). Changes in urban lichen diversity after a fall in sulphur dioxide levels in the city of Tampere, SW Finland. Annales Botanici Fennici, 38(4), 295-304.

Popov, V. A., \& Nehruc'ka, H. M. (1973). Metod shtuchnoji fumihaciji roslyn shkidlyvymy gazamy $\mathrm{v}$ toci povitrja [Fumigation method of artificial plants harmful gases in the air flow]. Introdukcija ta Eksperymental'na Ekolohija Roslyn, 3, 83-88 (in Ukrainian).

Pryseds'kyj, J. H. (1999). Statystychna obrobka rezul'tativ biolohichnykh eksperymentiv [Statistical analysis of the results of biological experiments] Juho-Vostok, Donec'k (in Ukrainian).

Pryseds'kyj, J. H. (2005). Paket prohram dlja provedennja statystychnoji obrobky rezul'tativ biolohichnykh eksperymentiv [The software package for the statistical analysis of the results of biological experiments. Tutorial]. DonNU, Donec'k (in Ukrainian).

Pryseds'kyj, J. H. (2014). Charakterystyka stijkosti derevnych ta chaharnykovykh roslyn do zabrudnennja povitrja spolukamy sirky, ftoru ta nitrohenu [Characteristic resistance of wood and shrubby plants to air pollution by sulfur, fluorine and nitrogen compounds]. Visnyk Kharkivskoho Natsionalnoho Universytetu Imeni V. N. Karazina. Seriia Biolohiia, 112, 162-167 (in Ukrainian).

Pryseds'kyj, J. H., \& Lykholat, Y. V. (2017) Adaptacija roslyn do antropohennych chynnykiv [Adaptation of plants to anthropogenic factors]. Vasyl Stus DonNU, Vinnytsya (in Ukrainian).

Pryseds'kyj, Y. (2016). Zminy aktyvnosti katalazy v lysti derevnykh chaharnykovykh roslyn v umovakh zabrudnennia povitria spolukamy fluoru, sulfuru ta nitrohenu [Changes catalase activity in leaves of wood and bush plants in the conditions of air pollution by compounds of fluor, sulfur and nitrogen]. Visnyk of Dnipropetrovsk University. Biology, Ecology, 24(2), 295-301 (in Ukrainian).

Rossychina, H., Lycholat, J., \& Kyrpyta, L. (2011). Aktyvnist' fermentivdetoksykatoriv aktyvnych form kysnju hazonoutvorjujuchykh trav za kompleksnoji diji toksykantiv [Activity of enzymes-detoxycators of active oxigen species of lawn forming grasses at complex toxic action]. Visnyk of Lviv University. Seriia Biolohichna, 56, 239-244 (in Ukrainian).

Rossychina-Halycha, H. S., Lycholat, J. V., \& Lysenko, N. O. (2014). Funkcionuvannja fermentiv antyoksydantnoji systemy v reproduktyvnykh orhanach Robinia pseudoacacia L. za umov promyslovoho mista [The functioning of antioxidant system enzymes in the reproductive organs Robinia pseudoacacia L. in conditions of industrial city]. Pytannja Stepovogo lisoznavstva ta lisovoji rekul'tyvaciji zemel', 43, 45-49 (in Ukrainian).

Rossykhina-Halycha, H. S., Lykholat, Y. V., \& Vinnychenko, O. M. (2013). Komponenty antyoksydantnoji systemy zakhystu yak pokaznyky stiikosti travianystykh roslyn, shcho zrostaiut u botanichnomu sadu DNU [The components of the antioxidant defense system as indicators of sustainability herb that grow in the botanical garden of DNU]. Visti Biosfernoho Zapovidnyka "Askaniia-Nova", 15, 188-194 (in Ukrainian).

Seyyednejad, S. M., Koochak, H., \& Vaezi, J. (2013). Changes in anti-oxidative enzymes activity, protein content and ascorbic acid level in Prosopis juliflora exposed to industrial air pollution. Journal of Biology and Today's World, 2(10), 482-492.

Sharma, G. K., Chander, C., \& Salemi, L. (1980). Environmental pollution and leaf cuticular variation in kudzu (Pueraria lobata Willd.). Annals of Botany, 45(1), 77-80.

Soda, C., Bussotti, F., Grossoni, P., Barnes, J., Mori, B., \& Tani, C. (2000). Impacts of urban levels of ozone on Pinus halepensis foliage. Environmental and Experimental Botany, 44(1), 69-82.

Sutinen, M.-L., Ratio, H., Nivala, V., Olikainen, R., \& Ritarp, A. (1996). Effects of emissions from copper-nickel smelters on the frost hardiness of Pinus sylvestris needles in the subarctic region. New Phytologist, 132, 503-512.

Wang, J., Zeng, Q., Zhu, J., Chen, C., Liu, G., \& Tang, H. (2014). Apoplastic antioxidant enzyme responses to chronic free-air ozone exposure in two different ozone-sensitive wheat cultivars. Plant Physiology and Biochemistry, 82, 183-193.

Wuytack, T., Abdelgawad, H., Staelens, J., Asard, H., Boeckx, P., Verheyen, K, \& Samson, R. (2013). The response of the foliar antioxidant system and stable isotopes $\left({ }^{13} \mathrm{C}\right.$ and $\left.{ }^{15} \mathrm{~N}\right)$ of white willow to low-level air pollution. Plant Physiology and Biochemisrty, 67, 154-161.

Yan-Ju, L., \& Hui, D. (2008). Variation in air pollution tolerance index of plants near a steel factory: Implications for landscape-plant species selection for industrial areas. Wseas Transactions on Environment and Development, $4(1), 24-32$. 